Made Kembar Nesa Sariawan, Kadek Yudiana, Gede Wira Bayu, (2020). Penggunaan Model Pembelajaran Numbered Heads Together dalam Meningkatkan Hasil Belajar IPA Jurnal Penelitian dan Pengembangan Pendidikan. Vol. 4 (2) pp. 325-333.

\title{
Penggunaan Model Pembelajaran Numbered Heads Together dalam Meningkatkan Hasil Belajar IPA
}

\author{
Made Kembar Nesa Sariawan ${ }^{*}$, Kadek Yudiana², Gede Wira Bayu ${ }^{3}$ \\ 123 Program Studi Pendidikan Guru Sekolah Dasar Universitas Pendidikan Ganesha
}

\begin{abstract}
Abstrak
Penelitian ini bertujuan untuk menganalisis nilai pembelajaran ipa melalui model pembelajaran Numbered Heads Together dengan menggunakan formula effect size pada sekolah dasar di Bali. Metode yang digunakan adalah meta-analisis. Populasi dalam penelitian ini adalah 29 artikel artikel yang diterbitkan dalam rentang waktu 2014-2020 pada jenjang sekolah dasar. Sampel dalam penelitian ini adalah 10 artikel yang sesuai dengan kriteria yang ditentukan. Hasil analisis yang telah dilakukan bahwa secara keseluruhan nilai rata-rata effect size sebesar 0,984, sehingga dikategorikan berefek besar yaitu $0,984 \geq 0,8$. Sehingga rata-rata tersebut membuktikan bahwa, pembelajaran dengan model Numbered Heads Together secara keseluruhan memiliki pengaruh yang besar terhadap hasil belajar IPA siswa. Sehingga dapat disimpulkan bahwa model pembelajaran Numbered Heads Together sangat cocok digunakan pada pembelajaran IPA, dikarenakan besar pengaruh model numbered heads together ada pada kategori besar dan sedang. Tentu hal tersebut didukung oleh manfaat model pembelajaran Numbered Heads together itu sendiri, yaitu penerimaan terhadap individu menjadi lebih besar, kepekaan dan toleransi, hasil belajar lebih tinggi, rasa harga diri menjadi lebih tinggi dan pemahaman yang lebih mendalam. Penelitian ini akan memberikan stimulus atau menjadi dasar bagi guru dalam menggunakan model Numbered Heads Together dalam menyampaikan materi dengan tepat, siswa mudah memahami materi, dan tujuan pembelajaran dapat tercapai.
\end{abstract}

\begin{abstract}
This study aims to find the effectivity of model numbered head together to student's science learning outcomes in elementary school. The method used in this study is meta-analysis. Population of the study are 29 journals that has published in national journals site that published around 2014-2020 at the elementary school level. Samples of the study are 10 journals which are based the criteria that have been determined. The overall results of the analysis effect of an average effect size is 0.984 . So it is categorized as large effect, $0.984 \geq 0.8$. So that the result proves that learning with the Numbered Heads Together model has a great influence on student's science learning outcomes. It can be concluded that numbered heads together model really fit with science learning, because the effect of numbered heads together model is in big and average categories. Certainly that it is supported by the benefit of numbered heads together model itself, which is improvement of individual acceptance, sensitivity and tolerance, higher learning outcome, higher dignity and deep understanding. This study will give stimuus or become the basis for teacher in using numbered heads together model in delivering the material in prisice, students easy to understand the material and learning objectives can be earned.
\end{abstract}

Keywords:

Meta analysis, effect size, numbered heads together model, learning outcome

\footnotetext{
* Corresponding author. 


\section{PENDAHULUAN}

Penelitian yang tepat, adalah penelitian yang dilakukan berhasil baik dari segi hasil maupun pelaksanaan yang berjalan dengan baik. Terkadang sebuah penelitian tidak mendapatkan hasil yang memuaskan atau hasil yang diinginkan. Tentu ada faktor yang menyebabkan hal tersebut. Faktor yang dimaksud yaitu faktor dari dalam dan dari luar. Faktor dari dalam yang dimaksud yaitu peneliti itu sendiri dilihat dari kesiapan mental dan bahan penelitian, dan pemilihan model yang digunakan dalam penelitian, serta menganalisis permasalahan yang ditemukan. Segi siswa itu sendiri, baik dari segi kognitif, kesiapan siswa. Sedangkan faktor dari luar yang dimaksud adalah lingkungan sekolah yang menjadi tempat penelitian. Sehingga perlu dikondisikan dan disiapakan dengan baik dalam mengadakan penelitian. Penelitian yang sering ditemukan adalah penelitian tentang penggunaan model di dalam pembelajaran. Ini tidak terlepas dari tingkat kemajuan di dunia pendidikan. Menurut (Mulyatiningsih, 2016)bahwa "pendidik yang kreatif akan selalu menciptakan ide-ide dalam merancang sistem pembelajaran baru yang mampu membuat peserta didik dapat mencapai tujuan belajarnya dengan penuh rasa puas". Hal senada juga disampaikan oleh (Nurdyansyah \& Amalia, 2018) bahwa "Proses pembelajaran hendaknya berlangsung secara interaktif, inspiratif, menyenangkan, menantang, memotivasi peserta didik untuk berpartisipasi aktif, serta memberikan ruang yang cukup bagi prakarsa, kreativitas, dan kemandirian sesuai dengan bakat, minat, dan perkembangan fisik serta psikologis peserta didik". Sehingga dari pendapat tersebut bagaimana peran guru dan model itu sangat besar dalam dalam meningkatkan mutu pendidikan siswa.

Peran model pembelajaran dalam menyampaikan materi adalah mempermudah guru dalam menyusun pembelajaran yang diinginkannya. Peran model pembelajaran sangat besar. Sebagai salah satu kunci dalam menyukseskan pembelajaran, tentu model pembelajaran sangat vital bagi guru menyambungkan apa yang ingin disampaikan guru kepada siswa dengan langkah-langkah yang sistematis. Model pembelajaran tercantum dan dituangkan dalam bentuk rpp yang disesuaikan dengan materi dan keadaan siswa. Sehingga ketika guru mengajar tidak lagi keluar dari konteks rancangan yang sudah ditentukan sebelumnya. Pentingnya penelitian penggunaan model pembelajaran dapat memberikan kebermanfaat bagi calon guru maupun guru yang sudah mengajar. Namun, pada kenyataannya pemahaman guru terhadap peran dari model pembelajaran tidak sesuai dengan langkah sistematis. Cenderung model pembelajaran hanya sebagai cindramata pada rencana pelaksaan pembelajaran (rpp). Padahal peran atau fungsi dari model pembelajaran adalah mempermudah guru dalam menyampaikan materi kepada siswa. Sehingga menjadi penyebab salah satu faktor indikator pembelajaran tidak tercapai.

Salah satu model yang digunakan dalam penelitian model pembelajaran adalah model pembelajaran Numbered Heads Together (NHT). Model pembelajaran Numbered Heads Together (NHT) merupakan salah satu model pembelajaran kooperatif yang menekankan kerjasama dan diskusi kelompok. Menurut (Dra. Ni Wayan Suniasih, 2017)bahwa "model pembelajaran kooperatif tipe NHT merupakan model yang dirancang untuk menuntut siswa untuk aktif dan bekerja sama dengan teman kelompoknya untuk menelaah materi dan memecahkan berbagai permasalah yang dihadapi siswa". Hal senada juga disampaikan oleh (Kusumawati \& Mawardi, 2016) bahwa " diskusi kelompok dengan menggunakan model pembelajaran tipe NHT dapat memberikan peluang kepada siswa untuk saling bertukar pikiran atau pendapat dan mencari jawaban yang paling tepat secara kolaboratif". Sedangkan menurut (Juliartini \& Arini, 2017) bahwa "NHT adalah model pembelajaran yang dapat memberikan rasa tanggung jawab kepada anak untuk menyelesaikan tugas dan melatih perkembangan otak anak untuk mencari tahu sendiri apa yang telah ditugaskan". Sehingga dapat disimpulkan bahwa model numberead heads together adalah suatu cara yang digunakan dalam menyampaikan materi berupa kegiatan diskusi dan setiap peserta mendapatkan nomor kelompok untuk menelaah materi dan memecahkan permasalahan yang dihadapi.

Model ini digunakan karena memiliki ciri khas tersendiri, yaitu penggunaan nomor kelompok ketika diskusi. Penyataan tersebut didukung oleh (Rofiqoh et al., 2015) bahwa "Numbered Heads Together (NHT) memiliki ciri-ciri khas yaitu guru menunjuk seorang siswa dengan menyebutkan salah satu nomor yang mewakili kelompoknya untuk mempresentasikan hasil kelompoknya itu ". Dalam penerapannya menurut (Nur et al., 2016) bahwa "siswa akan merasa senang berdiskusi dengan kelompoknya, guru sebagai fasilitator untuk mengatur jalannya diskusi maupun memberikan motivasi kepada siswa untuk belajar mandiri, berinteraksi antara siswa dengan siswa dan siswa dengan guru pengarah, serta keterlibatan guru dalam proses belajar mengajar berkurang". Sedangkan untuk langkahlangkah pembelajaran menurut (Lahir et al., 2017) bahwa a) siswa dibagi dalam kelompok-kelompok belajar, setiap siswa dalam setiap kelompok mendapat nomor, b) Guru memberikan tugas, c) Kelompok melakukan diskusi mengenai jawaban yang benar, d) Guru memanggil salah satu nomor siswa dengan 
nomor yang dipakai untuk melaporkan hasil kerjasamanya, e) Adanya tanggapan dari teman yang lain, dan f) Membuat kesimpulan dari pelaksanaan pembelajaran".

Penggunaan model Numbered Heads Together identik dengan pembelajaran kelompok yaitu pada pembelajaran IPA, karena pembelajaran IPA bukan hanya teori, tapi juga praktek berupa keterampilan dalam menyusun atau membuat karya yang berhubungan dengan pembelajaran IPA. (Widiana, 2016) bahwa "Pembelajaran IPA di sekolah dasar memegang peranan penting dalam pembelajaran IPA di jenjang-jenjang berikutnya sebab pengetahuan awal siswa sangat berpengaruh pada minat dan kecendrungan siswa untuk belajar IPA“. Pelajaran IPA adalah salah satu pelajaran yang di dapat di bangku sekolah dasar. Segala makhluk hidup dan makhluk mati menjadi objek materi dari pembelajaran IPA. Pelajaran IPA merupakan salah satu pelajaran yang dikategorikan melatih siswa melihat lingkungan sekitar dan memecahkan masalah dalam kehidupan sehari-hari. Menurut (Sayekti, 2015) bahwa "IPA merupakan kumpulan pengetahuan yang tersusun secara sistematis tentang gejala alam dan perkembangannya tidak hanya ditunjukkan oleh fakta-fakta, tapi juga timbulnya metode ilmiah dan sikap ilmiah". Sehingga dalam sangat penting pelajaran IPA untuk dipelajari. Karena IPA membuat kita mengetahui kehidupan yang luas ini. Menurut (Wahyuningsih et al., 2018) bahwa "pembelajaran IPA meliputi empat unsur yaitu produk, proses, aplikasi, dan sikap".

Namun, pada penelitian-penelitian yang dilakukan penggunaan model Numbered Heads Together terhadap hasil belajar IPA belum ada tindak lanjut terhadap hasil yang didapat, baik hasil yang didapat sesuai harapan maupun tidak. Padahal untuk mengetahui suatu keberhasilan penggunaan model adalah melakukan studi kepustakaan untuk mengetahui penyebab keberhasilan model yang digunakan atau sebagai pembanding terhadap penelitian yang dilakukan. Sehingga hasil tersebut bisa sebagai dasar atau landasan terhadap penelitian yang dilakukan. Selain itu, hasil penelitian perlu diketahui seberapa besar pengaruh model Numebered Heads Together terhadap hasil belajar IPA, besar pengaruh tersebut peneliti dapat mengetahui bahwa penelitian yang dilakukan berhasil atau tidak. Banyak penelitian-penelitian berupa jurnal dan artikel yang tersedia atau telah dipublikasikan di berbagai website resmi dan diakui oleh akademis tentang pendidikan. Jurnal atau artikel yang berasal dari mahasiswa dari berbagai kampus yang ada di Indonesia. Namun, penelitian atau hasil penelitian tersebut tidak banyak dirangkum atau di uji kembali keefektifan hasil suatu penelitian tersebut.

Meta-analisis sebagai salah satu metode bisa digunakan, untuk penelitian yang meneliti data-data hasil penelitian sebelumnya. Berbagai kegiatan yang perlu dilakukan dalam mengetahui dampak model Numbered Heads Together terhadap hasil belajar IPA. Menurut (Ula et al., 2020) bahwa "meta analisis merupakan penelitian yang dilakukan dengan cara merangkum, mereview, dan menganalisis data penelitian dari beberapa penelitian yang sudah ada dan bisa dengan referensi dari beberapa buku". Hal senada juga sampaikan oleh (Hararap, 2020) bahwa "meta analisis adalah suatu penelitian yang mengumpulkan, mengolah dan menyajikan data yang telah dianalisis secara sistematis dan objektif yang hasilnya dapat digunakan untuk memecahkan masalah atau menguji hipotesis dengan cara melakukan penyelidikan terhadap penelitian-penelitian yang telah ada". Sedangkan menurut (Septiani et al., 2019) bahwa "meta-analisis merupakan kajian atas sejumlah hasil penelitian dalam masalah yang sejenis". Sehingga dapat disimpulkan meta analisis adalah analisis untuk memecahkan masalah dengan penyelidikan terhadap penelitian-penelitian yang ada.

Dalam bidang pendidikan, penelitian berbasis kepustakaan yang menggunakan metode metaanalisis telah dilakukan di jenjang pendidikan dan berbagai mata pelajaran. Namun, untuk penelitian berbasis kepustakaan dengan metode meta-analisis terbaru mengenai model Numbered Heads Together pada pembelajaran IPA di jenjang pendidikan sekolah dasar belum ada. Penelitian yang terbaru adalah tentang Penggunaan Media Gambar Untuk Meningkatkan Hasil Belajar Siswa Dalam Pembelajaran IPA oleh (Utami, 2020). Sedangkan penelitian kepustakaan terbaru mengenai model Numbered Heads Together pada penelitian (Hastuti et al., 2019) yaitu Keefektifan Model Pembelajaran Numbered Heads Together Berbantu Media Panelpa (Papan Flanel IPA) Terhadap Hasil Belajar. Sehingga perlu adanya penelitian tentang kepustakaan tentang penggunaan model Numbered Heads Together dalam meningkatkan hasil belajar IPA. Beranjak dari latar belakang dan masalah tersebut, perlu dilakukan penelitian dengan metode meta-analisis pada jurnal nasional yang telah terakreditasi. Maka dari itu, perlu dilakukan penelitian dengan judul "Penggunaan Model Pembelajaran Numbered Heads Together Dalam Meningkatkan Hasil Belajar Ipa Pada Sekolah Dasar ".

Penelitian ini didukung oleh (Indarsih \& Ardyaningrum, 2016) bahwa "hasil penelitian menunjukkan bahwa model pembelajaran kooperatif tipe Numbered Head Together (NHT) ini efektif digunakan karena rata-rata yang didapatkan di kelas eksperimen 95 dan terdapat $100 \%$ siswa yang mendapatkan nilai di atas KKM (Kriteria Ketuntasan Minimal) dari jumlah siswa". Serta (Yani, 2019) bahwa "hasil penelitian ini menunjukkan bahwa sebelum penelitian skor rata-rata hasil belajar siswa 62.93 masih tergolong sedang, pada siklus I skor rata-rata hasilbelajar siswa mengalami 
peningkatan menjadi 64.93dari skor ideal yang mungkin dicapai 100. Skor hasil belajar ini tergolong kategori sedang.Pada siklus II skor rata-rata hasil belajar siswa 75.73 dari skor ideal yang mungkin dicapai 100 dan berada dalam kategori tinggi". Perbedaan yang mendasar dari penelitian ini dengan penelitian lainnya adalah bahan penelitian dan serta kriteria dalam menentukan bahan penelitian. bahan penelitian ini yaitu artikel yang sudah dipublish yang menjadi sumber skunder, serta salah satu kriteria pengujian hipotesis dibatasi pada uji t. Tujuan penelitian ini adalah untuk menganalisis besar pengaruh penggunaan model numbered heads together dalam meningkatkan hasil belajar IPA siswa pada sekolah dasar.

\section{METODE PENELITIAN}

Jenis penelitian ini adalah penelitian kepustakaan. Metode penelitian yang digunakan yaitu metaanalisis. Menurut (Djatikusumo, 2016) bahwa "meta analisis adalah suatu analisis integratif sekunder dengan menerapkan prosedur statistik terhadap hasil-hasil pengujian hipotesis penelitian". Subjek penelitian ini, adalah sumber sekunder berupa jurnal, buku, dan essay. Sampel dalam penelitian berupa artikel atau jurnal yang telah dipublikasikan secara nasional, khususnya artikel yang telah dipublikasikan. Instrumen penelitian ini adalah pedoman dokumentasi, menurut (Thalha Alhamid dan Budur Anufia Ekonomi Islam, 2019) bahwa "pedoman dokumentasi yang memuat garis-garis besar atau kategori yang akan dicari datanya". Bahwa terdapat 10 artikel dari 29 artikel yang akan diteliti yang lulus dari kriteria yang ditentukan yaitu sebagai berikut: (1) dibuat atau ditulis oleh civitas akademika (dosen maupun mahasiswa), (2) penelitian dilakukan di Indonesia, (3) penelitian dalam rentang 2014 sampai 2019, (4) penelitian dilakukan pada jenjang pendidikan SD, (5) subyek penelitian berupa penggunaan model numberead heads together terhadap hasil belajar IPA, (6) pengujian hipotesisis dibatasi pada uji $t$. Sehingga jurnal atau artikel yang dijadikan subjek penelitian harus memenuhi kriteria tersebut.

Teknik pengumpulan data menggunakan teknik obervasi. Observasi menurut (Fauziah et al., 2019) adalah metode pengumpulan data penelitian dengan melalui pengamatan terhadap objek yang diteliti. Yang dilakukan adalah mengidentifikasi sumber-sumber sekunder seperti artikel, jurnal, atau web yang berhubungan dengan variabel dalam judul penelitian. Teknik analisis yang digunakan dalam penelitian ini adalah teknik analisis besar atau effect size. Menurut (TELA et al., 2019) bahwa "effect size adalah ukuran mengenai besarnya efek suatu variabel pada variabel lain besarnya perbedaan maupun hubungan yang bebas dari pengaruh sampel". Sedangkan menurut Ningsih (R. Diani et al., 2018) bahwa "effect size juga dapat dianggp sebagai ukuran mengenai tingkat keberhasilan peneliti". Teknik ini digunakan untuk mencari besarnya pengaruh atau stimulus terhadap sasaran dituju, baik itu hasil belajar ataupun keterampilan. Hasil penelitian yang sudah dipublikasikan akan diseleksi terlebih dahulu dengan kriteria yang sudah ditentukan. Pengumpulan data yang sudah dilakukan, terdapat dua puluh sembilan jurnal yang bertema pembelajaran dengan model Numbered Heads Together. Jurnal yang berjumlah dua puluh sembilan tersebut, dianalisis baik isi dan data yang dibutuhkan untuk menghitung effect size, sehingga mengkrucut menjadi sepuluh jurnal yang sesuai dengan kriteria yang sudah ditentukan. Ada dua rumus yang digunakan dalam menentukan effect size yaitu rumus Gain dan rumus Cohen's. Menurut (H. Diani et al., 2019) bahwa "Gain adalah selisih antara nilai postest dan posttest". Sedangkan menurut Ambarwati \& Setiawan, (2019) bahwa penelitian data Cohen's dimaksudkan untuk melihat besarnya variabel a terhadap variabel $\mathrm{b}$. Adapun secara ringkas langkah-langkah analisis untuk menghitung effect size pada artikel yaitu pada Gambar 0.1 berikut: 


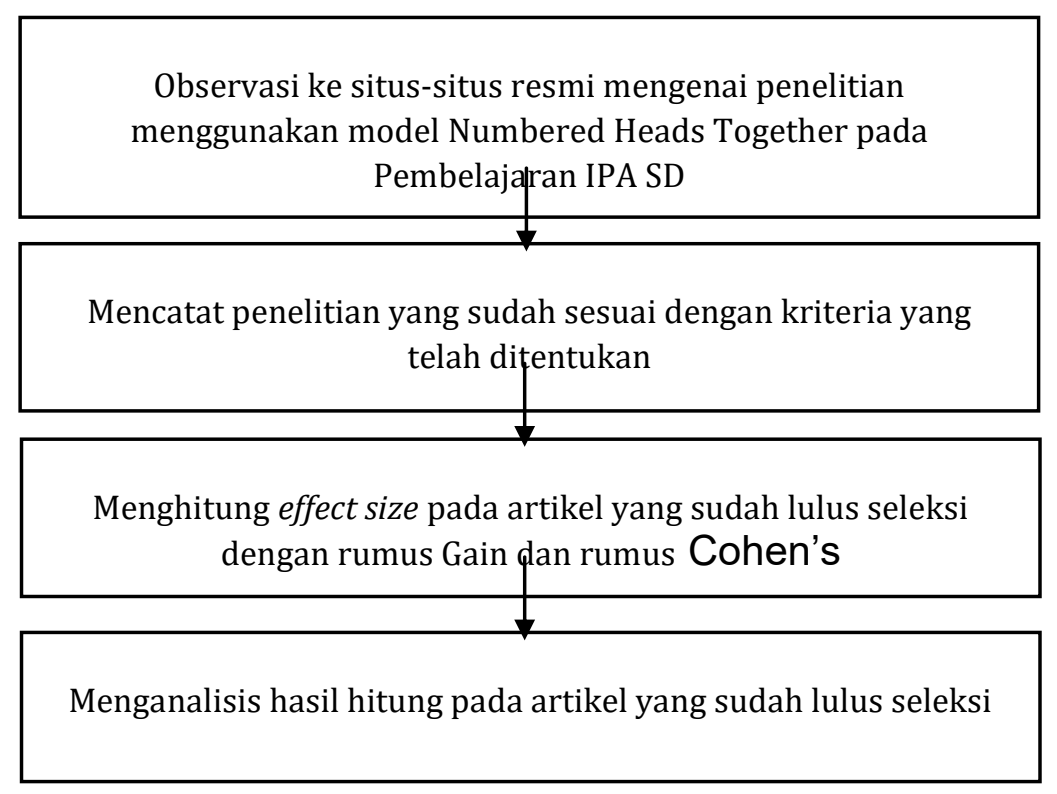

Gambar 1. Bagan proses hitung effect size

\section{ANALISIS DAN PEMBAHASAN}

Tabel 1. Data Pengelompokan Effect Size Secara Keseluruhan

\begin{tabular}{|c|c|c|c|c|c|c|}
\hline \multirow[t]{2}{*}{ No } & \multirow{2}{*}{$\begin{array}{c}\text { Kode } \\
\text { Jurnal }\end{array}$} & \multicolumn{3}{|c|}{ Sub-Unit } & \multirow{2}{*}{$\begin{array}{c}\text { Nilai } \\
\text { Effect } \\
\text { Size } \\
\end{array}$} & \multirow[t]{2}{*}{ Keterangan } \\
\hline & & Wilayah & $\begin{array}{l}\text { Variabel } \\
\text { Terikat }\end{array}$ & Variabel Bebas & & \\
\hline 1 & A3 & Buleleng & Hasil Belajar & $\begin{array}{l}\text { Model } \\
\text { Pembelajaran } \\
\text { Kooperatif Tipe } \\
\text { Numbered Head } \\
\text { Together }\end{array}$ & 1,86 & \\
\hline 2 & A1 & Karangasem & Hasil Belajar & $\begin{array}{lr}\text { Model } & \text { Pembelajaran } \\
\text { Kooperatif } & \text { Tipe } \\
\text { Numbered } & \text { Head } \\
\text { Together } & \\
\end{array}$ & 1,52 & \\
\hline 3 & A7 & Badung & $\begin{array}{l}\text { Kompetensi } \\
\text { Pengetahuan }\end{array}$ & $\begin{array}{l}\text { Model Numbered Head } \\
\text { Together (NHT) berbasis } \\
\text { Tri Hita Karana. }\end{array}$ & 1,26 & \\
\hline 4 & A9 & Denpasar & $\begin{array}{l}\text { Kompetensi } \\
\text { Pengetahuan }\end{array}$ & $\begin{array}{lr}\text { Model } & \text { Pembelajaran } \\
\text { Kooperatif } & \text { Tipe } \\
\text { Numbered } & \text { Heads } \\
\text { Together } & \text { Berbantuan } \\
\text { Media Konkret }\end{array}$ & 1,089 & Besar \\
\hline 5 & A2 & Buleleng & Hasil Belajar & $\begin{array}{lr}\text { Model } & \text { Pembelajaran } \\
\text { Kooperatif } & \text { Tipe } \\
\text { Numbered } & \text { Head } \\
\text { Together (NHT) } & \\
\end{array}$ & 0,92 & \\
\hline 6 & A6 & Denpasar & Hasil Belajar & $\begin{array}{lr}\text { Model } & \text { Pembelajaran } \\
\text { Kooperatif } & \text { Tipe } \\
\text { Numbered } & \text { Head } \\
\text { Together (NHT) Berbasis } \\
\text { Proyek }\end{array}$ & 0,84 & \\
\hline 7 & A10 & Badung & Hasil Belajar & $\begin{array}{l}\text { Model Pembelajaran } \\
\text { Problem Solving Dengan }\end{array}$ & 0,65 & \\
\hline
\end{tabular}




\begin{tabular}{|c|c|c|c|c|c|c|}
\hline \multirow[b]{2}{*}{8} & \multirow[b]{2}{*}{ A8 } & \multirow[b]{2}{*}{ Tabanan } & \multicolumn{3}{|c|}{ Setting NHT } & \multirow{4}{*}{ Sedang } \\
\hline & & & Hasil Belajar & $\begin{array}{l}\text { Model Pembelajaran } \\
\text { Numbered Head } \\
\text { Together Berlandaskan } \\
\text { Tri Kaya Parisudha }\end{array}$ & 0,63 & \\
\hline 9 & A4 & Badung & $\begin{array}{l}\text { Karakter dan } \\
\text { Hasil Belajar }\end{array}$ & $\begin{array}{l}\text { Model Pembelajaran } \\
\text { NHT Berbasis Tri Hita } \\
\text { Karana }\end{array}$ & 0,56 & \\
\hline \multirow[t]{2}{*}{10} & A5 & Denpasar & $\begin{array}{l}\text { Kompetensi } \\
\text { Pengetahuan }\end{array}$ & $\begin{array}{l}\text { Model Pembelajaran } \\
\text { NHT Berbasis Concept } \\
\text { Mapping }\end{array}$ & 0,50 & \\
\hline & \multicolumn{4}{|c|}{ Rerata effect size secara keseluruhan } & 0,984 & Besar \\
\hline
\end{tabular}

Berdasarkan Tabel 1 tersebut, bahwa pengelompokkan hasil perhitungan ke dalam efek besar dan sedang Mengacu pada klasifikasi effect size pada rumus Cohen bahwa secara keseluruhan terdapat enam jurnal yang dikategorikan besar dan empat jurnal yang dikategorikan sedang. Hasil analisis yang dilakukan, bahwa secara keseluruhan rata-rata effect size model pembelajaran numbered heads together pada penelitian yang bersifat eksprimen dari sepuluh jurnal yang dianalisis mencapai angka 0,984. Sehingga dikategorikan berefek besar yaitu $0,984 \geq 0,8$. Oleh karena itu, rata-rata tersebut membuktikan bahwa pembelajaran dengan model numbered heads together secara keseluruhan memiliki pengaruh yang besar terhadap hasil belajar IPA siswa. Keseluruhan jurnal yang sudah dianalisis dengan rumus Cohen's dan rumus Gain, paling besar effect size nya pada penelitian Pengaruh Model Pembelajaran Kooperatif Tipe Numbered Head Together Terhadap Hasil Belajar IPA Siswa Kelas IV oleh (Witari et al., 2018) yaitu 1,86. Serta yang terendah penelitian dengan judul Pengaruh Model Pembelajaran NHT Berbasis Concept Mapping Terhadap Kompetensi Pengetahuan IPA Siswa Kelas IV Sd oleh (Drs. Ida Bagus Surya Manuaba, 2017) yaitu 0,50.

Berdasarkan hasil analisis tersebut, maka model pembelajaran Numbered Heads Together mampu meningkatkan hasil belajar IPA, tentu ini dibantu oleh kelebihan dari model NHT. Menurut (Ferryka, 2019) bahwa "dua kelebihan model pembelajaran kooperatif tipe NHT yaitu siswa mampu mengikuti kegiatan diskusi dengan sungguh-sungguh dan siswa yang pandai dapat mengajari siswa yang kurang pandai". Bukan hanya itu, menurut (Parwata, 2019) bahwa "dengan model pembelajaran NHT siswa diberi kesempatan untuk mengalami sendiri atau melakukan sendiri, mengikuti suatu proses, mengamati suatu objek, menganalis, membuktikan dan menarik kesimpulan sendiri tentang suatu objek dan keadaan suatu proses pembelajaran mata pelajaran tertentu". Di samping itu keefektifan model pembelajaran Numbered Heads Together tidak terlepas dari manfaat penggunaan model ini. Seperti yang dikatakan oleh Lundgren (Hapsari, 2017) bahwa "manfaatnya yaitu memperbaiki kehadiran, penerimaan terhadap individu menjadi lebih besar, konflik antara pribadi berkurang, meningkatkan kebaikan budi, kepekaan dan toleransi, hasil belajar lebih tinggi, rasa harga diri menjadi lebih tinggi, perilaku mengganggu menjadi lebih kecil, pemahaman yang lebih mendalam". Disamping manfaat tersebut, pengaruh penggunaan media, atau konsep-konsep lain juga memberikan dampak yang signifikan pada pengaplikasian model Numbered Heads Together seperti multimedia, benda konkret, konsep tri hita karana, tri kaya parisuda, maupun kolaborasi dengan model kooperatif lainnya. Hasil ini juga didukung oleh penelitian yang dilakukan oleh (Natalia et al., 2019) bahwa hasil penelitian menunjukkan bahwa nilai probabilitas signifikansi 0,040 yang artinya lebih kecil dari 0,05 $(0,040<0,05)$. Hasil penelitian ini dapat disimpulkan bahwa terdapat perbedaan efektivitas hasil belajar IPA siswa dengan menggunakan model pembelajaran kooperatif tipe STAD (Student Teams Achievement Divisions) dan NHT (Numbered Heads Together) SD Gugus Joko Tingkir.

Penelitian ini memiliki perbedaan dengan penelitian sebelumnya, seperti penelitian yang dilakukan oleh (Hastuti et al., 2019) dengan judul "Keefektifan Model Pembelajaran Numbered Heads Together Berbantu Media Panelpa (Papan Flanel IPA) Terhadap Hasil Belajar". Perbedaan terletak pada dari (1) sampel penelitian. Pada penelitian ini, menggunakan sumber sekunder berupa artikel yang sudah dipublish, sedangkan penelitian yang dilakukan oleh Hastuti, dkk menggunakan sampel siswa kelas $\mathrm{V}$ di SD Negeri 03 Sungapan Pemalang. (2) teknis analisis yang digunakan. Pada penelitian ini menggunakan teknis analisis effect size (besarnya pengaruh variabel terhadap variabel lainnya), sedangkan penelitian hastuti, dkk menggunakan analisis uji t. Serta (3) segi konteks yang diteli. Pada penelitian ini, konteksnya pada penelitian dari 2014-2019 yang dipublish, sedangkan penelitian Hastuti, dkk konteksnya pada lingkup sekolah langsung. 


\section{KESIMPULAN}

Hasil temuan penelitian yang telah dilakukan, maka dapat disimpulkan bahwa keseluruhan dari sepuluh hasil kajian penelitian yang relevan yang telah diseleksi berdasarkan kriteria yang telah ditentukan dan telah dihitung dengan menggunakan meta-analisis untuk mengetahui effect size dari penggunaan model pembelajaran numbered heads together mampu meningkatkan hasil belajar IPA siswa pada kelompok eksperimen yang lebih besar dari kelompok kontrol. Dari hasil penelitian yang didapatkan bahwa model pembelajaran numbered heads together sangat efektif dengan rata-rata effect size secara keseluruhan dikategorikan besar. Sehingga model pembelajaran numbered heads together sangat cocok digunakan pada pembelajaran IPA. Tentu hal tersebut di dukung oleh manfaat dari model pembelajaran numbered heads together itu sendiri, yaitu penerimaan terhadap individu menjadi lebih besar, kepekaan dan toleransi, hasil belajar lebih tinggi, rasa harga diri menjadi lebih tinggi, pemahaman yang lebih mendalam. Namun, ada beberapa saran yang perlu disampaikan dalam upaya perbaikan dan penelitian-penelitian yang serupa di masa datang yaitu sebagai berikut: Dalam menggunakan model numbered heads together pada pembelajaran IPA, guru harus menyesuaikan dengan materi dan situasi kelas, pada penelitian kepustakaan, diharapkan peneltian yang akan dilakukan oleh akademis menggunakan sampel penelitian yang banyak dan dalam penelitian harus teliti dan detail.

\section{DAFTAR PUSTAKA}

Ambarwati, L. H., \& Setiawan, I. (2019). RELASI ANTARA KEMAMPUAN PEMAHAMAN MATEMATIK SISWA SMP DENGAN METODE PEMBELAJARAN AKTIF TIPE EVERYONE IS A TEACHER HERE. Journal On Education, 01, 300. http://www.jonedu.org/index.php/joe/article/view/67/55

Diani, H., Irwandi, \& Fujiani, D. (2019). Pembelajaran Fisika dengan Model Brain Based Learning (BBL): Dampak pada Keterampilan Berpikir Kritis. Indonesian Journal of Sciene and Mathematcs Education, 2. https://doi.org/https://doi.org/10.24042/ijsme.v2i3.4360

Diani, R., Asyhari, A., \& Julia, O. N. (2018). PENGARUH MODEL RMS (READING, MIND MAPPING AND SHARING) TERHADAP KEMAMPUAN BERPIKIR TINGKAT TINGGI SISWA PADA POKOK BAHASAN IMPULS DAN MOMENTUM. Jurnal Pendidikan Edutama. https://doi.org/10.30734/jpe.v5i1.128

Djatikusumo, koko nakulo. (2016). No TitlePengaruh Literasi Keuangan dan Pendidikan Keuangan Terhadap Perilaku Keuangan, Sebuah Meta Analisis. 13-20. https://scholar.google.co.id/scholar?hl=id\&as_sdt=0\%2C5\&q=Pengaruh+Literasi+Keuangan+dan+ Pendidikan+Keuangan+terhadap+Perilaku+Keuangan\%2C+Sebuah+Meta+Analisis\&btnG=

Dra. Ni Wayan Suniasih, S. (2017). PENGARUH MODEL PEMBELAJARAN KOOPERATIF TIPE NHT BERBANTUAN QUESTION CARDS TERHADAP KOMPETENSI PENGETAHUAN IPA. MIMBAR PGSD Undiksha. https://doi.org/10.23887/jjpgsd.v5i2.10660

Drs. Ida Bagus Surya Manuaba, S. (2017). PENGARUH MODEL PEMBELAJARAN NHT BERBASIS CONCEPT MAPPING TERHADAP KOMPETENSI PENGETAHUAN IPA SISWA KELAS IV SD. MIMBAR PGSD Undiksha. https://doi.org/10.23887/jjpgsd.v5i2.10752

Fauziah, Z., Yulianingsih, Y., \& Syamiyah, S. (2019). Meningkatkan Kemampuan Kognitif Anak pada Pembelajaran Sains Melalui Metode Eksperimen. (JAPRA) Jurnal Pendidikan Raudhatul Athfal (JAPRA). https://doi.org/10.15575/japra.v2i1.5311

Ferryka, P. Z. (2019). Meningkatkan Hasil Belajar Matematika Melalui Model Pembelajaran Number Head Together (NHT)padaSiswa Kelas I SD Negeri 4 Barenglor. Jurnal Pendidikan Modern. https://doi.org/10.37471/jpm.v4i2.14

Hapsari, A. E. (2017). PENERAPAN MODEL PEMBELAJARAN KOOPERATIF TIPE NUMBERED HEADS TOGETHER BERBANTUAN MEDIA INTERAKTIF UNTUK MENINGKATKAN AKTIVITAS DAN PRESTASI BELAJAR SISWA. Scholaria: Jurnal Pendidikan Dan Kebudayaan. https://doi.org/10.24246/j.scholaria.2017.v7.i1.p1-9 
Hararap, D. G. S. (2020). No TitleMeta-Analisis Penggunaan Model Pengembangan Dalam Meningkatkan Kualitas Pembelajaran Ipa. vol 8(Vol 8 No 2 (2020): Vol. 8 No. 2 Mei 2020). https://doi.org/https://doi.org/10.37081/ed.v8i2.1744

Hastuti, H. W., Baedowi, S., \& Mushafanah, Q. (2019). No TitleKeefektifan Model Pembelajaran Numbered Heads Together Berbantu Media Panelpa (Papan Flanel IPA) Terhadap Hasil Belajar. International $\begin{array}{llllll}\text { Journal of Elementary } & \text { Education., } & \text { vol } & \text { 108-115. }\end{array}$ https://ejournal.undiksha.ac.id/index.php/IJEE/article/view/18513/10938

Indarsih, S., \& Ardyaningrum, M. (2016). EFEKTIVITAS MODEL PEMBELAJARAN KOOPERATIF TIPE NUMBERED HEAD TOGETHER (NHT) TERHADAP HASIL BELAJAR IPA KELAS III DI SD NEGERI GUNUNGSAREN SRANDAKAN BANTUL YOGYAKARTA TAHUN AJARAN 2015/2016. 7, 10. http://ejournal.almaata.ac.id/index.php/LITERASI/article/view/374/328

Juliartini, N. ., \& Arini, N. . (2017). PENERAPAN MODEL PEMBELAJARAN NHT UNTUK MENINGKATKAN

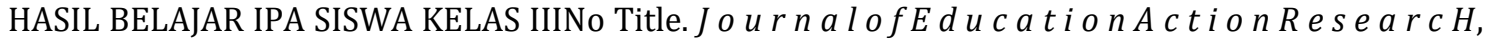
vol 1, 240-250. https://doi.org/http://dx.doi.org/10.23887/jear.v1i3.12688

Kusumawati, H., \& Mawardi, M. (2016). PERBEDAAN PENERAPAN MODEL PEMBELAJARAN KOOPERATIF TIPE NHT DAN STAD DITINJAU DARI HASIL BELAJAR SISWA. Scholaria: Jurnal Pendidikan Dan Kebudayaan. https://doi.org/10.24246/j.scholaria.2016.v6.i3.p251-263

Lahir, S., Ma'ruf, M. H., \& Tho'in, M. (2017). PENINGKATAN PRESTASI BELAJAR MELALUI MODEL PEMBELAJARAN YANG TEPAT PADA SEKOLAH DASAR SAMPAI PERGURUAN TINGGI. JURNAL ILMIAH EDUNOMIKA. https://doi.org/10.29040/jie.v1i01.194

Mulyatiningsih, E. (2016). PENGEMBANGAN MODEL PEMBELAJARAN. 8. http://staffnew.uny.ac.id/upload/131808329/pengabdian/7cpengembangan-modelpembelajaran.pdf

Natalia, N., Kristin, F., \& Anugraheni, I. (2019). PERBEDAAN EFEKTIVITAS MODEL PEMBELAJARAN KOOPERATIF TIPE STAD DAN NHT DITINJAU DARI HASIL BELAJAR IPA SISWA KELAS 4 SD GUGUS JOKO TINGKIR. VOX EDUKASI: Jurnal Ilmiah Ilmu Pendidikan. https://doi.org/10.31932/ve.v10i1.332

Nur, M. I., Salam, M., \& Hasnawati. (2016). Pengaruh Penerapan Model Pembelajaran Kooperatif Tipe Numbered Heads Together (NHT) Terhadap Hasil Belajar Matematika Siswa Kelas VII SMP Negeri 1 Tongkuno. Jurnal Penelitian Pendidikan Matematika.

Nurdyansyah, N., \& Amalia, F. (2018). MODEL PEMBELAJARAN BERBASIS MASALAH PADA PELAJARAN IPA MATERI KOMPONEN EKOSISTEM. 8. http://eprints.umsida.ac.id/id/eprint/1611

Parwata, I. W. (2019). PENGARUH MODEL PEMBELAJARAN NHT TERHADAP HASIL BELAJAR GEOMETRI DITINJAU DARI KEMAMPUAN SPASIAL SISWA SD. Indonesian Journal Of Educational Research and Review, 2, 11. https://doi.org/http://dx.doi.org/10.23887/ijerr.v2i3.21368.g13314

Rofiqoh, F., Mahardika, I. K., \& Yushardi. (2015). PENGARUH MODEL PEMBELAJARAN KOOPERATIF TIPENUMBERED HEADS TOGETHER (NHT) DISERTAI MEDIAMONOPOLI GAMES TERINTEGRASI PENDEKATANPROBLEM SOLVING PADA PEMBELAJARANFISIKA DI SMA. Jurnal Pembelajaran Fisika, 4, 6. https://jurnal.unej.ac.id/index.php/JPF/article/view/2637/2131

Sayekti, I. C. (2015). PERAN PEMBELAJARAN IPA DI SEKOLAH DALAM MEMBANGUN KARAKTER ANAK. 7. https://publikasiilmiah.ums.ac.id/xmlui/bitstream/handle/11617/6010/13_Ika Candra Sayekti.pdf? sequence $=1 \&$ isAllowed $=\mathrm{y}$

Septiani, T., Prima, N., \& Nisak Fitri. (2019). META-ANALISIS MODEL INQUIRY BASED LEARNING UNTUK PEMBELAJARAN IPA DAN FISIKA PADA ABAD 21. Pillar of Physics Education, 12, 8. http://ejournal.unp.ac.id/students/index.php/pfis/article/download/7910/3724 
TELA, T., YULIAN, V. N., \& BUDIANINGSIH, Y. (2019). PENGARUH MODEL PEMBELAJARAN KOOPERATIF TIPE THINK PAIR SHARE (TPS) TERHADAP PENINGKATAN KEMAMPUAN PEMECAHAN MASALAH MATEMATIS SISWA. BIORMATIKA : JURNAL ILMIAH FAKULTAS KEGURUAN DAN ILMU PENDIDIKAN. https://doi.org/10.35569/biormatika.v5i01.464

Thalha Alhamid dan Budur Anufia Ekonomi Islam. (2019). INSTRUMEN PENGUMPULAN DATA. Sekolah Tinggi Agama Islam Negeri (STAIN).

Ula, N., Hartatik, S., Nafiah, \& Akhwani. (2020). Meta-analisis Pengaruh Media Visual Terhadap Minat Belajar Siswa SD Pada Pembelajaran Matematika. Jurnal Matematika Dan Pendidikan Matematika, 11, 11. http://journal.upgris.ac.id/index.php/aksioma/article/view/6223/3289

Utami, Y. setyo. (2020). PENGGUNAAN MEDIA GAMBAR UNTUK MENINGKATKAN HASIL BELAJAR SISWA DALAM PEMBELAJARAN IPA. JURNAL PENDIDIKAN Dan KONSELING Research \& Learning in Primary Education, 1, https://journal.universitaspahlawan.ac.id/index.php/jpdk/article/view/607/514

Wahyuningsih, Y., Rchmawati, I., Setiawan, A., \& Ngazizah, N. (2018). HOTS (Higher Order Thinking Skills) dan Kaitannya dengan Keterampilan Generik SAINS dalam Pembelajaran IPA SD. Prosiding Seminar Nasional Pendidikan Dasar.

Widiana, I. W. (2016). PENGEMBANGAN ASESMEN PROYEK DALAM PEMBELAJARAN IPA DI SEKOLAH DASAR. JPI (Jurnal Pendidikan Indonesia). https://doi.org/10.23887/jpi-undiksha.v5i2.8154

Witari, I. G. A., Mahadewi, L. P. P., \& Rati, N. W. (2018). Pengaruh Model Pembelajaran Kooperatif Tipe Numbered Head Together terhadap Hasil Belajar IPA Siswa Kelas IV. Journal PGSD Universitas Pendidikan Ganesha Jurusan PGSD.

Yani, A. (2019). PENERAPAN MODEL PEMBELAJARAN KOOPERATIF TIPE NUMBERED HEADS TOGETHER(NHT) DENGAN MEDIA KARTU INDEKS DALAM MENINGKATKAN HASIL BELAJAR IPA TERPADU SISWA KELAS VIIISMP NEGERI 3 SABBANGPAR. Jurnal Imiah Pendidikan "Mappedeceng," 11. https://osf.io/preprints/inarxiv/9vkmh/ 